\title{
bioentrepreneur
}

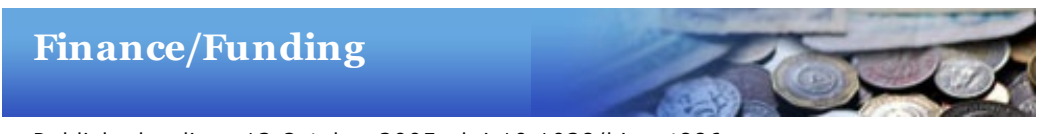

Published online: 13 October 2005, doi:10.1038/bioent886

$\checkmark$ Nice PIPEs

Stacy Lawrence $\underline{1}$

Stacy Lawrence is a freelancer in Oakland, California

Fledgling biotechs and their original investors are increasingly looking at PIPEs to fill the funding void.

Capital markets in the US continue to be a slog for all early-stage biotechs, but particularly the privately held variety. This, together with pressures from their investors to float shares on public markets ever earlier, is leading more fledgling biotechs to try their luck raising capital as public companies. Trouble is, initial public offerings (IPOs) aren't producing much in the way of payoffs or daily trading volume.

All is not as grim as it sounds. Interest in private investment in public equities (PIPEs) is growing to the delight of many a biotech upstart. PIPEs are particularly appealing for biotechs that have not yet produced products or proved their viability sufficiently to attract the broader investor pool required for a large IPO and sustained

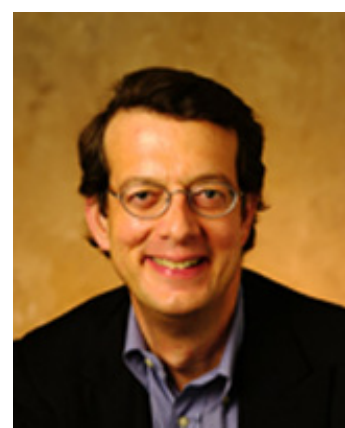

Oxford Bioscience Partners

PIPE Fitter: Oxford Bioscience general partner Michael Lytton market capitalization growth.

The third quarter was one of the best for biotech PIPE fundraising since the frothy days of 2000 according to data from San Carlos, Californiabased industry research group BioCentury. A healthy $\$ 842$ million was raised in the quarter: that's almost double the amount raised during the same period in 2004 . The number of PIPEs thus far in 2005 is roughly akin to that of 2004 . The average and median amount raised this year per financing, however, has risen from $\$ 16$ million to $\$ 20$ million, and $\$ 10$ million to $\$ 13$ million, respectively (see Fig. 1 ).

Figure 1: PIPEs pull through

\begin{tabular}{|l|l|} 
The number of PIPEs has stayed relatively \\
stable, but the average and median amount \\
raised is on the rise.
\end{tabular}

Typically in a PIPE transaction, a small group of private investors led by a hedge fund and the firm's original venture capital (VC) backers purchase shares in a publicly held biotech that is often young and struggling to attract the attention of Wall Street analysts and large institutional investors like mutual funds and pension funds.

CInterest in private investment in public equities (PIPEs) is growing to the delight of many a biotech upstart.

Fortunately for biotechs, PIPE investors are increasingly keen on the life sciences asset class, observes Nick Oust, vice president at San Franciscobased investment bank and research firm ThinkEquity Partners. Oust says that young biotech companies have become the most likely to avail themselves of a PIPE. As a result, the market has become accustomed to the idiosyncrasies of early-stage biotechs, even those younger than five years old.

When investing in biotech PIPEs, "there's a higher level of risk involved given the clinical risks," Oust argues, "but there are a number of investors willing to take that risk for a significantly higher return." 
Today in the US, PIPEs account for fully $10-20 \%$ of the funds raised by public biotechs. Throughout most of the 1990s, they accounted for less than $5 \%$. Until recently, almost all PIPE funding went to US companies. In the last few years, however, more has started to go to European biotechs (see Table 1). So far this year, one-fifth of all biotech PIPE proceeds went to European biotechs; that's up from just a one-tenth share last year.

PIPEs are not, by any means, appropriate for all biotechs. Follow-on offerings, for example, bring firms more capital-three times more on average-and typically come with better terms. But, PIPEs can be a faster, cheaper route. These are two key selling points when capital is running dry, especially for biotech firms. Also, PIPEs don't require biotechs to manage the mind-numbing, time-consuming and expensive 'road shows' that are required to pitch and woo institutional investors.

And as Richard Tullo, a special situations analyst at Liberum Research in New York, notes: "Usually PIPE deals are done at a steep discount to the contemporaneous market price of the underlying securities and are either special preferred shares, unit deals or have penalties and restrictive convents. Additionally, a PIPE, like a venture capital round of financing, can also enforce penalties on the issuer if it does not register the PIPE securities and or meet other milestones." And these features transfer risk from the PIPE investor back to the company, creating some compelling low cost hedging, which in turn creates some attractive upside opportunities that would not be available without the PIPE.

Biotechs pursuing a PIPE often turn to private investors, often the very same venture capitalists that supported it through earlier years as a private company who are already familiar with the company and its prospects. In the most recent quarter, venture capital firms including London-based Abingworth Management, Boston-based Oxford Bioscience Partners, New York-based OrbiMed Advisors and Menlo Park, Californiabased Venrock Associates all participated in PIPEs for biotech companies they had originally invested in just a few years earlier when the biotech firms were still private companies.

C6'PIPE investing is an opportunity for us to put more money to work in the very best companies in our portfolio,' says Oxford Bioscience Partners Managing Partner Michael Lytton.\%

For example, Oxford Bioscience Partners, which specializes in investment in early-stage, private life sciences companies, has invested in PIPEs for Hayward, California-based DNA sequencing company Solexa, braincomputer interface builder Foxborough, Massachusetts-based Cyberkinetics Neurotechnology Systems and RNA interference researcher Sirna Therapeutics located in San Francisco.

"Right now, early- to medium-stage biopharmaceutical therapeutic opportunities are not in favor in the market," says Oxford general partner Michael Lytton. "For us, this has been a buying opportunity for companies that we know really well. PIPE investing is an opportunity for us to put more money to work in the very best companies in our portfolio."

Biotechs often turn to PIPEs almost immediately after floating their shares in one public offering or another. Solexa became a public company through a reverse merger in March and then turned to a PIPE a month later to properly finance the firm. The firm completed its $\$ 32.5$ million PIPE offering in the third quarter.

As we head into the winter, biotech entrepreneurs hope these pipes don't start freezing up.

\section{Web links}

\section{Websites referenced:}

- BioCentury

- Oxford Bioscience Partners

- Solexa

- ThinkEquity Partners 
Table 1: Europe takes to PIPEs

\begin{tabular}{|l|l|c|c|c|c|}
\hline \multicolumn{7}{|c|}{ PIPE investment by region } \\
\hline & \multicolumn{1}{|c|}{$\mathbf{2 0 0 1}$} & $\mathbf{2 0 0 2}$ & $\mathbf{2 0 0 3}$ & $\mathbf{2 0 0 4}$ & $\mathbf{2 0 0 5}$ YTD \\
\hline Asia-Pacific & $\$ 19,948,000$ & NA & $\$ 18,127,056$ & $\$ 25,586,650$ & $\$ 35,288,361$ \\
\hline Europe & $\$ 46,620,073$ & $\$ 29,957,869$ & $\$ 92,601,245$ & $\$ 278,619,559$ & $\$ 360,248,747$ \\
\hline North America & $\$ 1,723,186,288$ & $\$ 958,219,248$ & $\$ 1,920,273,368$ & $\$ 2,442,744,850$ & $\$ 1,517,003,748$ \\
\hline
\end{tabular}

So far this year, European companies have laid claim to almost one-fifth of global biotech PIPE investments. Source: BioCentury

\section{SPRINGER NATURE}

(C) 2019 Nature is part of Springer Nature. All Rights Reserved.

partner of AGORA, HINARI, OARE, INASP, ORCID, CrosSRef, COUNTER and COPE 